\title{
A New Screening Method for Probiotic Lactic Acid Bacteria in the Lactobacillus acidophilus Group by Using Carbohydrate Probes
}

\author{
Tadao SAITO, Atsushi MATSUMURA, Haruki KITAZAWA, Yasushi KAWAI, \\ Takatoshi ITOH and Honoh HASHIBA ${ }^{1}$ \\ Graduate School of Agricultural Science, Tohoku University, \\ Aoba-ku, Sendai-shi 981-8555, Japan \\ ${ }^{1}$ Technical Research Institute, Snow Brand Milk Products Co., Ltd., \\ Kawagoe-shi 350-1165, Japan \\ (Received August 19, 1999 ; Accepted November 10, 1999)
}

\begin{abstract}
To select probiotic strains of the Lactobacillus (L.) acidophilus group with high adhesion to human intestinal tracts for developing the functional yogurt, a new screening method using biotinylated carbohydrate probe (BCP) was introduced. After incubation of living cells of 30 strains of the L. acidophilus group with 5 kinds of BCPs which possess representative partial structures of the sugar chains constituting of human colonic mucin, the interaction between cell-surface lectins and $B C P$ were evaluated. The highest reactivity was detected in 19 strains (about 63\%) with a trisaccharide probe (GalNAc $\alpha(1 \rightarrow 3)[\operatorname{Fuc} \alpha(1 \rightarrow 2)] \mathrm{Gal} \beta 1 \rightarrow)$. The cell-surface lectin activity was first clearly confirmed in the B group of the $L$. acidophilus group. The adhesion evaluation score (AE score, total sum of each absorbance of 5 BCPs samples) is considered to be useful as an indicator for selection of the probiotic strains which have high adhesiveness in human gastrointestinal tract.
\end{abstract}

Animal Science Journal 71 (1), 103-108, 2000

Key words : Lactobacillus acidophilus, Cell-surface lectin, Biotinylated carbohydrate probe, Sugar chain, Surface-layer protein

Lactobacillus (L.) acidophilus group lactic acid bacteria (LAB) isolated from human feces are considered to survive in the host's gastrointestinal tracts, and to possess beneficial effects in their host's health when they are used in the functional yogurt ${ }^{8}$. The $L$. acidophilus group was classified into two big category of the group $\mathrm{A}\left[L\right.$. acidophilus ( $\mathrm{A}_{1}$ subgroup), $L$. crispatus $\left(\mathrm{A}_{2}\right)$, L. amylovorus $\left(\mathrm{A}_{3}\right)$, L. gallinarum $\left.\left(\mathrm{A}_{4}\right)\right]$ and the group $\mathrm{B}\left[L\right.$. gasseri $\left(\mathrm{B}_{1}\right)$, L. johnsonil $\left.\left(\mathbf{B}_{2}\right)\right]$ by DNA-DNA homology and cell-wall composition analysis ${ }^{4,5}$. Recently, L. gasseri ( $\mathrm{B}_{1}$ subgroup) is known to be a dominant strain among the $L$. acidophilus group living in human gastrointestinal tracts $^{2)}$.
In the group A strains, the lectin-like proteins in surface layer protein (SLP) which was detected by hemagglutination (HA) test has recognized by Mukai et al. ${ }^{6)}$ and by us $^{10)}$ to have an important role for the cell adhesion through binding to carbohydrate portions of the colonic mucous layer. However, the reactivity of the HA test is not so sensitive and the interpretation of adhesion mechanism between cellsurface lectins (receptors) and sugar chains (ligands) on erythrocytes was really complicated.

Recently, we have pointed out that the HA assay was not a good indicator for selecting strains having high adhesion to human intestinal tract and developed the new screening method with combination using

Corresponding : Tadao SAITO (fax : +81 (0) 22-717-8715, e-mail : tsaito@bios.tohoku.ac.jp) 


\section{SAITO, MATSUMURA, KITAZAWA, KAWAI, ITOH and HASHIBA}

Carnoy's-fixed human colonic mucous layer and polystyrene beads coated with rat-colonic mucin (RCM) instead of human mucin ${ }^{9}$. Although this method was useful to select probiotic LAB, the preparation of RCM and the slices of Carnoy's-fixed human colon is costly and time-consuming.

Biotinylated carbohydrate probe (BCP, commercial name is biotinylated polymeric (BP)-probe) was designed for detection of the carbohydrate binding proteins (lectins) directly on the cell membrane, organelle and in cytoplasm ${ }^{1,3)}$. Podolsky ${ }^{7)}$ has reported the chemical structure of 21 kinds of acidic and neutral O-glycosidic sugar chains (mucin type) combining to human colonic mucin and the most representative sugar chain are as follows.

GalNAc $\alpha$ 1-3Gal $\beta 1-3 \mathrm{GalNAc} \beta 1-3 \mathrm{Gal} \beta 1-4 \mathrm{GlcNAc} \beta 1-3 \mathrm{GalNAc}-\mathrm{Thr}$ (or Ser)

\section{Fuc $\alpha$ 1-2 NeuAc $\alpha 2-6$}

We selected 5 kinds of BCP probes, which have the same partial structure of mono-, di- and trisaccharide moiety combining the most common sugar chains as shown above. Therefore, the probes were expected to be high-sensitive tool to detect faint lectin activity on cell-surface and to specify the lectin character instead of our former screening method using RCM.

In this paper, we describe a new screening method using $\mathrm{BCP}$ that can differentiate $\mathrm{LAB}$ strains among the $L$. acidophilus group with high adhesion to human gastrointestinal tracts.

\section{Materials and Methods}

\section{Bacteria}

Table 1 shows names and origins of 30 strains of the Lactobacillus (L.) acidophilus group of LAB used in this study according to the recent classification ${ }^{4,5)}$. Fourteen strains were purchased from the Japan Collection of Microorganisms (JCM, Wako, Japan) and another strains were isolated from mainly human feces in Technical Research Institute of Snow Brand Milk Products Co., Ltd. (SBT, Kawagoe, Japan) or in our laboratory (LA). L. acidophilus SBT2062 ( $\mathrm{A}_{1}$ subgroup) was a selected a strain which showed high adhesion to RCM-coated polystyrene beads reported in our previous paper ${ }^{9}$.

\section{Materials}

Anim. Sci. J. 71 (1) : 103-108, 2000
Table 1. Names and origins of 30 strains of Lactobacillus acidophilus group lactic acid bacteria used in this experiment

\begin{tabular}{|c|c|}
\hline Subgroup & Strains (Origin) \\
\hline \multicolumn{2}{|l|}{ A group } \\
\hline L. acidophilus $\left(\mathrm{A}_{1}\right)$ & $\begin{array}{l}\text { JCM } 1132^{\mathrm{T}}(\mathrm{a}), \operatorname{SBT} 279(\mathrm{a}) \\
\operatorname{SBT} 2062 \text { (c), LA } 67(\mathrm{a})\end{array}$ \\
\hline L. crispatus $\left(\mathbf{A}_{2}\right)$ & $\begin{array}{l}\text { JCM } 1185^{\mathrm{T}}(\mathrm{f}), \operatorname{JCM} 8778 \text { (a), } \\
\text { SBT } 265 \text { (a), SBT } 266 \text { (a), } \\
\text { LA } 87 \text { (a), LA } 135 \text { (a) }\end{array}$ \\
\hline L. amylovorus $\left(\mathbf{A}_{3}\right)$ & $\begin{array}{l}\operatorname{JCM} 1126^{\mathrm{T}}(\mathrm{j}), \operatorname{JCM} 1034(\mathrm{~b}), \\
\operatorname{JCM} 2125 \text { (b), SBT } 264 \text { (a), } \\
\text { SBT } 10021 \text { (a) }\end{array}$ \\
\hline L. gallinarum $\left(\mathrm{A}_{4}\right)$ & $\begin{array}{l}\operatorname{JCM} 2011^{\mathrm{T}}(\mathrm{g}), \operatorname{JCM} 8782(\mathrm{i}), \\
\text { SBT } 316(\mathrm{~d})\end{array}$ \\
\hline \multicolumn{2}{|l|}{ B group } \\
\hline L. gasseri $\left(\mathrm{B}_{1}\right)$ & $\begin{array}{l}\text { JCM } 1131^{\mathrm{T}} \text { (b), JCM } 1025 \text { (b), } \\
\text { JCM } 8787 \text { (a), SBT } 267 \text { (a), } \\
\text { SBT } 269 \text { (a), LA } 39 \text { (a), } \\
\text { LA } 158 \text { (a), LA } 187 \text { (a) }\end{array}$ \\
\hline L. johnsonii $\left(\mathrm{B}_{2}\right)$ & $\begin{array}{l}\operatorname{JCM} 2012^{\mathrm{T}}(\mathrm{h}), \operatorname{JCM} 2122(\mathrm{e}) \\
\operatorname{JCM} 8793(\mathrm{k}), \operatorname{SBT} 277(\mathrm{a})\end{array}$ \\
\hline
\end{tabular}

T : type strain

(a): human feces, (b) : human intestine, (c) : unknown, (d) : commercial yogurt, (e) : sour milk, (f) : human eye, (g) : chicken crop, (h) : human blood, (i) : chicken feces, (j) : cattle waste-corn fermentation, $(\mathrm{k})$ : pig feces.

Five kinds of BCP were purchased from Seikagaku Industries Co., Ltd., (Tokyo, Japan) as follows : GlcNAc (N-acetylglucosamine) $\beta 1 \rightarrow$ probe, NeuAc (N-acetylneuraminic acid) $\alpha 2 \rightarrow$ probe, Gal (Dgalactose) $\beta(1 \rightarrow 4)$ GlcNAc (N-acetyllactosamine, LacNAc) $\beta 1 \rightarrow$ probe, GalNAc (N-acetylgalactosamine ) $\alpha(1 \rightarrow 3) \mathrm{Gal} \beta 1 \rightarrow$ probe and GalNAc $\alpha(1 \rightarrow 3)$ [Fuc (L-fucose) $\alpha(1 \rightarrow 2)]$-Gal $\beta 1 \rightarrow$ probe. Each probe had a partial structure of the most representative O-type sugar chain combined to human colonic mucin $^{\text {7) }}$ as described above. Sugar content, biotin content and molecular weight of each probes were 20 mol. $\%, 5 \mathrm{~mol} \%$ and $30-40 \mathrm{kDa}$, respectively. Each BCP ( $1 \mathrm{mg}$ ) was dissolved in $2.0 \mathrm{ml}$ of $10 \mathrm{mM}$ sodium phosphate buffer containing $0.05 \%(\mathrm{w} / \mathrm{v}) \mathrm{NaCl}$ (PBS, 
$\mathrm{pH} 7.2$ ), then stored at $-20^{\circ} \mathrm{C}$ until using.

Preparation of 3 types of cells from L. acidophilus SBT 2062 strain

L. acidophilus SBT 2062 strain was successively propagated 3 times in Lactobacilli MRS broth (Difco Laboratories, Detroit, U.S.A.) at $37^{\circ} \mathrm{C}$ for $24 \mathrm{hrs}$. After centrifugation $(8,000 \mathrm{rpm}, 20 \mathrm{~min})$ of the culture, precipitated cells were washed 3 times with PBS followed by water, and then lyophilized. The lyophilized cells $(15 \mathrm{mg})$ were suspended in $2.0 \mathrm{ml}$ of PBS $\left(\mathrm{OD}_{660} \fallingdotseq 2.0\right)$ and swelled for $1 \mathrm{hr}$ at room temperature (Sample A). After centrifugation of a part of the Sample A $(0.5 \mathrm{ml})$, cells were treated with $4 \mathrm{M}$ guanidine hydrochloride $(\mathrm{GHCl})$ solution $(1 \mathrm{ml})$ at $37^{\circ} \mathrm{C}$ for $2 \mathrm{hrs}$ with gentle shaking to remove SLP. The cells were recovered by centrifugation $(10,000$ $\mathrm{rpm}, 10 \mathrm{~min}$ ), washed 3 times with PBS followed by water, and then resuspended in $0.5 \mathrm{~m} l$ of PBS $\left(\mathrm{OD}_{660}\right.$ $\fallingdotseq 2.0$, Sample B). Another part of the sample A (0.5 $\mathrm{ml}$ ) was heated at $65^{\circ} \mathrm{C}$ for $10 \mathrm{~min}$ (Sample C). These 3 types of cells (Sample A, B and C) were subjected to the binding assay with BCP.

Binding assay with BCP to 3 types of L. acidophilus SBT 2062 cells

Each BCP solution $(5 \mu l)$ was added to a cellsuspension of the Sample A, B and C $(20 \mu l)$ prepared from $L$. acidophilus SBT 2062. After incubation at $37^{\circ} \mathrm{C}$ for $2 \mathrm{hrs}$ with mixing at every $15 \mathrm{~min}$, the supernatant was removed by centrifugation $(8,000 \mathrm{rpm}, 20$ $\mathrm{min})$. Precipitated cells were washed 3 times with PBS followed by water, and then were resuspended in water $(20 \mu l)$. After mixing with $5 \mu l$ of Horse Radish Peroxidase (HRP) conjugated streptoavidin (SA, 2,000 fold dilution with water, Zymed Laboratories INC., San Francisco, U.S.A.), the samples were incubated at $4^{\circ} \mathrm{C}$ for $1 \mathrm{hr}$ with mixing at every $10 \mathrm{~min}$. After rinsing of cells with PBS followed by water at 3 times, the cells were mixed with tetramethylbenzydine solution $(100 \mu l$, TMBZ colordeveloping regent kit, Sumitomo Bakelite Co., Ltd., Tokyo, Japan) and left for $10 \mathrm{~min}$. After adding 100 $\mu l$ of the stopping solution, the supernatant obtained by centrifugation were transferred to a well of a microtiter plate (96-wells, Sumitomo Bakelite Co., Ltd.) and its absorbance was measured at $450 \mathrm{~nm}$ by a mircotiter plate reader Model 450 (Bio-Rad Laboratories Inc., California, U.S.A.). Three cell samples without addition of BCP were also reacted with HRP-SA and then TMBZ solution, and absorbance of the supernatant were set as blank.

Binding assay with BCP to 30 strains of the $L$. acidophilus group

The following operation was performed with 30 strains of the L. acidophilus group of LAB listed in Table 1. Each lyophilized cell $(7.5 \mathrm{mg})$ prepared from 30 strains was suspended in PBS $\left(\mathrm{OD}_{660} \doteqdot 2.0\right)$ and swelled for $1 \mathrm{hr}$ at room temperature. These samples $(20 \mu l)$ were reacted with 5 kinds of BCP solution $(5 \mu l)$ and then with HRP-SA and TMBZ, followed by $\mathrm{OD}_{450}$ measurement under the same conditions as above mentioned. These experiments were repeated three times and the absorbance was expressed mean \pm standard deviation. ( $\overline{\mathrm{X}} \pm \mathrm{SD})$.

\section{Results}

Binding assay with 5 kinds of BCP to 3 types of cells from $L$. acidophilus SBT 2062 was intended to reveal the binding specificity of the probes to cell-surface of L. acidophilus strains. Figure 1 shows the change of binding ability on each BCP against the 3 type of cells (cell A (intact cells, white bar), cell B (cells after $\mathrm{GHCl}$ treatment, shaded bar) and cell $\mathrm{C}$ (cells after heating, black bar)). The binding ability of the probes was represented as "relative binding intensity" $\left[\left(\mathrm{OD}_{\text {cell B }}\right.\right.$ or $\left.\left.\mathrm{OD}_{\text {cell }} \mathrm{C} / \mathrm{OD}_{\text {cell A }}\right) \times 100 \%\right]$ that was calculated from each absorbance of cell samples at $450 \mathrm{~nm}$.

In the cell $\mathrm{B}$ (shaded bar), the binding of BCP except a NeuAc-probe extremely decreased after $\mathrm{GHCl}$ treatment $(36-63 \%)$. The result indicates that a part of binding receptors on the cell-surface was removed by the $\mathrm{GHCl}$ extraction treatment. In a sole increasing effect on the binding with a NeuAcprobe after $\mathrm{GHCl}$ treatment, binding sites may newly appear on the cell-surface after partial removal of SLP. In the cell C (black bars), the binding ability of all probes markedly decreased after heating (36$67 \%$ ). The result indicates that the binding receptors locating on the cell surface were proteinaceous lectin(s) and also partially denatured or inactivated by the heating treatment. The specific binding between

Anim. Sci. J. 71 (1) : 103-108, 2000 


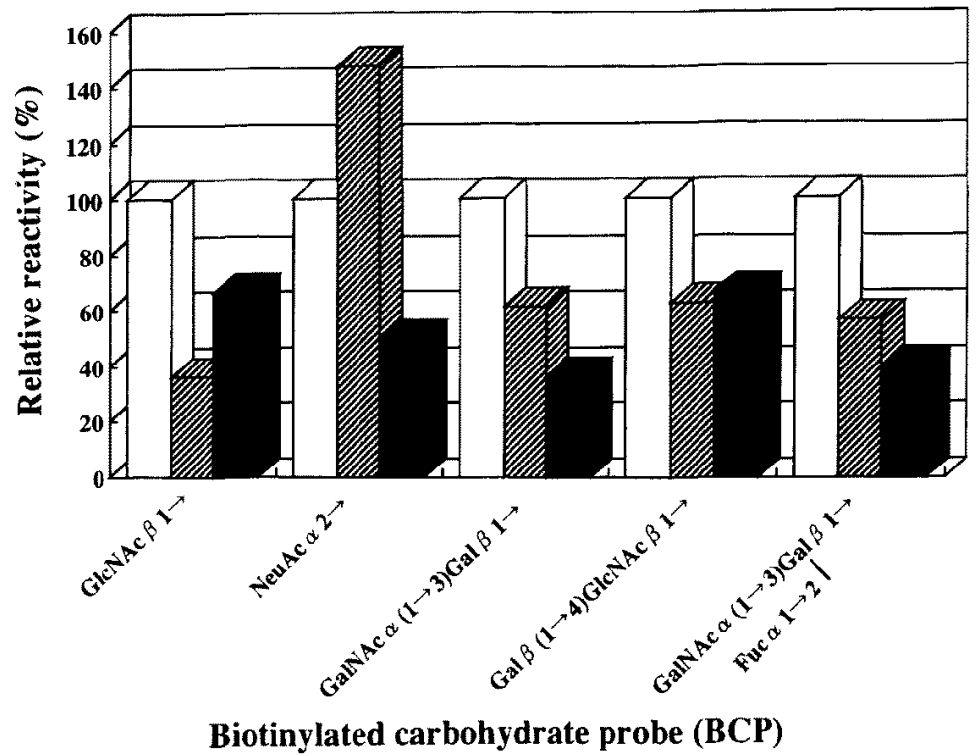

Fig. 1. The change of binding activity of 5 kinds of BCP on the cells of L. acidophilus SBT 2062 strain after guanidine hydrochloride extraction and heating treatment.

White bar, no treatment (intact cells) ; Shaded bar, guanidine hydrochloride (GHCl) extraction ; Black bar, heating treatment $\left(65^{\circ} \mathrm{C}, 10 \mathrm{~min}\right)$.

cell-surface lectins and $\mathrm{BCP}$, which was observed in this strain of L. acidophilus SBT 2062 (Fig. 1), was considered to be able to apply to other strains in Talbe 1.

After the preliminary experiments (Fig. 1), the binding assay with 5 kinds of BCP to cell-surface lectins of the $L$. acidophilus group was performed. Figure 2 shows the ranking of well reacted 10 strains plus $L$. acidophilus SBT 2062 strain and the relative reactivity on the assay with the probes to the cells from 30 strains of the $L$. acidophilus group. The highest reactivity to all probes was observed in a strain of $L$. gallinarum JCM 8782 ( $\mathrm{A}_{4}$ subgroup, from chicken feces), therefore each absorbance was expressed as "relative reactivity" after the absorbance of JCM 8782 was set to $100 \%$. All 30 strains reacted with more than at least one of the probes tested (each data not shown). The binding tendency of each probe to cellsurface lectins could not be classified among subgroups $\left(A_{1} \sim B_{2}\right)$ of the L. acidophilus group and apparently varied among 30 strains (strain-specific). The reactivity was increased in proportion to the molecular weight of sugar portion of $\mathrm{BCP}$, especially a GalNAc $\alpha(1 \rightarrow 3)$ [Fuc $\alpha(1 \rightarrow 2)$ ] Gal(trisaccharide) $\beta$ $1 \rightarrow$ probe was highly reacted $\left(\mathrm{OD}_{450}=0.5-0.6\right)$ with 19 strains (about 63\%). The lectin activity on the cell-surface in the group B of the L. acidophilus group was first proposed in this report. These results suggest that not only the A group but the $\mathbf{B}$ group of the L. acidophilus group possess cell-surface lectins which can participate in binding with sugar chains of human colonic mucin.

Table 2 shows the ranking (best 5) and the "Adhesion Evaluation score (AE score)" for the selected 5 strains of $L$. acidophilus group with high adhesion ability calculated from the results (Fig. 2) by the BCP method. The final AE score in each strain was calculated from the sum of each absorbance from $5 \mathrm{BCP}$ samples. The 5 strains (JCM 8782, 2011, 8787, 2012 and 2125 ) which has high evaluation score more than 2.000 was expected to be a probiotic LAB for the functional yogurt. 


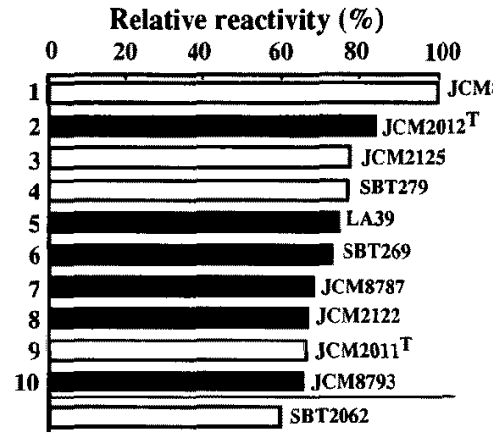

Gal $\beta$ 1-4GIcNAc $\beta$ 1-

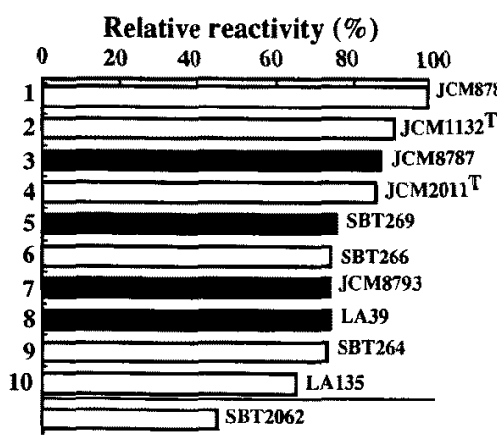

GaINAc $\alpha$ 1-3Gal $\beta$ 1-

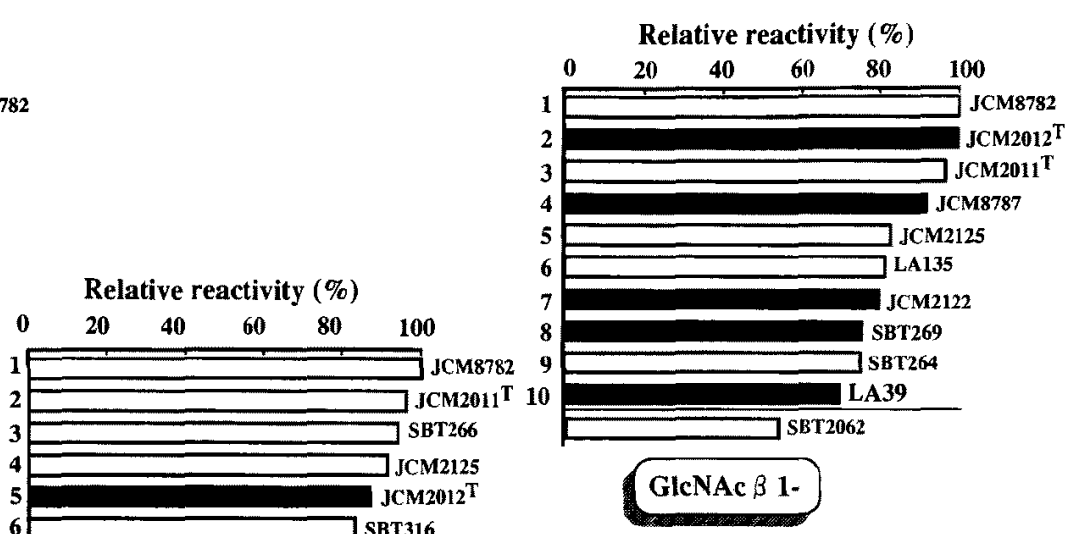

Relative reactivity (\%)

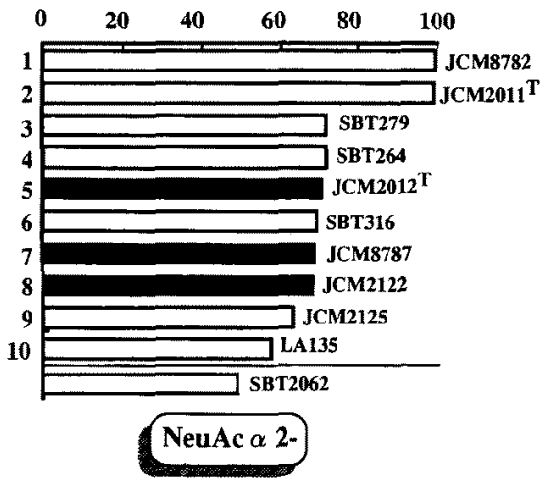

Fig. 2. The ranking of well-reacted 10 strains with 5 kinds of BCP among the cells from 30 strains of the $L$. acidophilus group LAB.

White bar, the A group strain ; Black bar, the B group strain.

The relative reactivity $(\%)$ of the strain of L. acidophilus SBT 2062 was shown as a reference data.

Table 2. Ranking (Best 5) and adhesion evaluation score of L. acidophilus group LAB selected with high adhesion ability and calculated from BCP binding assay

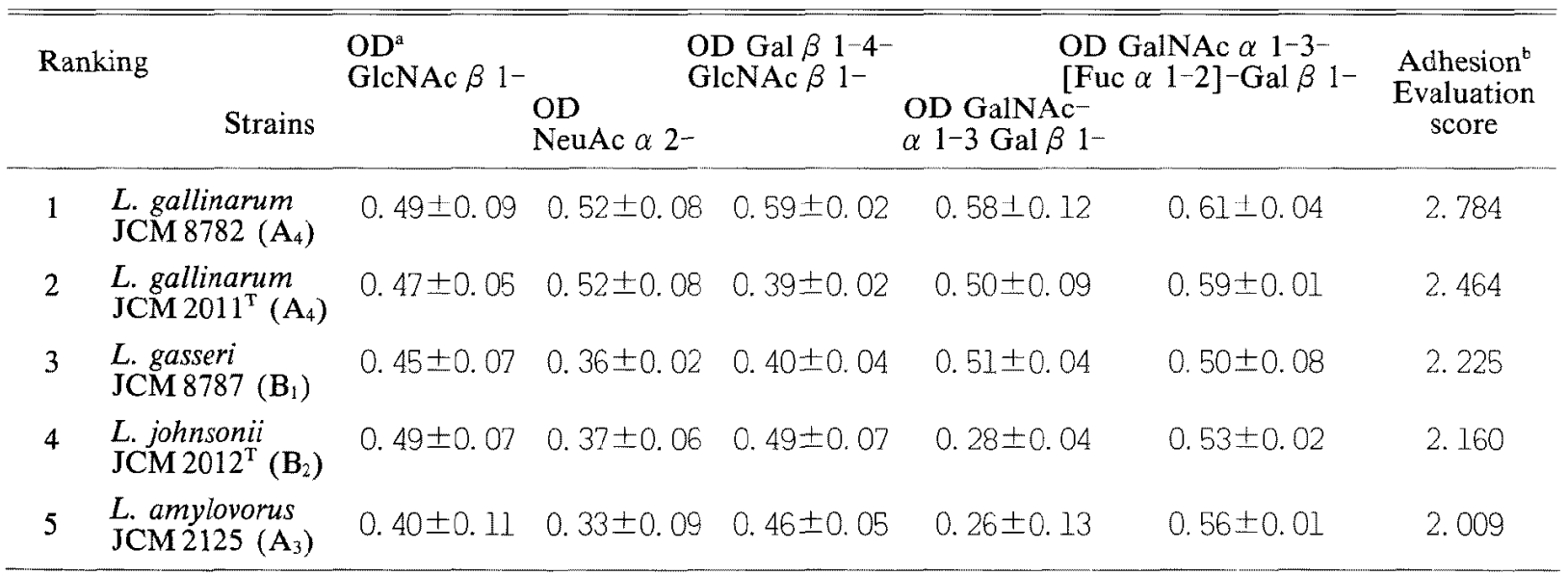

${ }^{a} \mathrm{OD}$ represents the absorbance $(\overline{\mathrm{X}} \pm \mathrm{SD})$ at $450 \mathrm{~nm}$ by using each biotinylated carbohydrate probe $(\mathrm{BCP})$.

${ }^{\mathrm{b}}$ Adhesion Evaluation score (AE score) $=$ The sum of each absorbance from 5 BCP samples. 


\section{Discussion}

In our previous report on the lectin screening ${ }^{10)}$ in the $L$. acidophilus group using ovine erythrocytes, the most cells in the group A strains showed the hemagglutination (HA) activity, but no active strains were detected in the group B strains. The results led the conclusion that the A group strains of the $L$. acidophilus group have cell-surface lectins which expect to combine to colonic mucosa, but the adhesion mechanism in the group B strains remained unclear. In our later screening method ${ }^{9)}$ of the combination with rat colonic mucin (RCM) coated polystyrene beads and Carnoy's-fixed human colonic tissue, HA assay was evidenced to be a no good indicator for selection of the strains with high adhesion to the human intestinal tracts. Although the RCM beads method was useful for the mass-screening of strains in the group A, it could not still determine the adhesion activity of the $B$ group $L$. acidophilus strains, because of the less existence and weak activity of lectins on their cell-surface and also high background problem of the beads method. Moreover, as it is not so easy to obtain RCM from rat's colon (a few $\mathrm{mg}$ from colons of 100 rats) and human normal colon tissue, BCP which is easy to obtain as commercial reagents is prominent.

In this report, the location of the cell-surface lectins in the group B of the L. acidophilus group was first confirmed through "the BCP method". This new method using 5 kinds of BCPs is expected to be a good technique for the selection of high adherent strains to the carbohydrate portion of human colonic mucin. The selected strains (Table 2) with high AE score were considered to serve in dairy, medical and pharmaceutical field as probiotic LAB having strong possibility for initial adhesion and the later colonization ability in human gastrointestinal tracts.

\section{Acknowledgment}

This work was supported in part by a Grant-in-Aid for Developmental Scientific Research to T. Saito (No. 10660254) from the Ministry of Education, Science, and Culture, Japan.

\section{References}

1) Abramenko IV, Gluzman DF, Korchagina EYu, Zemlyanukhina TV, Bovin NV. Oligosaccharidebinding molecules on the surface of human hemopoietic and lymphoid cells. FEBS Letters, 307 : 283-286. 1992.

2) Benno $Y$, Endo $K$, Mizutani $T$, Namba $Y$, Komori T, Mitsuoka T. Comparison of fecal microflora of elderly persons in rural and urban areas of Japan. Applied and Environmental Microbiology, $55: 1100^{-}$ 1105. 1989.

3) Coppee I, Gabius HJ, Danguy A. Histochemical analysis of carbohydrate moieties and sugar-specific acceptors in the kidneys of the laboratory mouse and the golden spiny mouse (Acomys russatus). Histology and Histopathology, $8: 673-683.1993$.

4) Johnson JL, Phelps CF, Cummins CS, London J, Gasser F. Taxonomy of the Lactobacillus acidophilus group. International Journal of Systematic Bacteriology, 30:53-68. 1980.

5) Lauer E, Helming C, Kandler O. Heterogeneity of the species Lactobacillus acidophilus (Moro) Hansen and Moquot as revealed by biochemical characteristics and DNA-DNA hybridisation. Zentralblatt für Bakteriologie, Mikrobiologie, und Hygiene. 1. Abt, Originale, C, Allgemeine, angewandte, und ökologische Mikrobiologie C1 : 150-168. 1980.

6) Mukai $T$, Arihara $\mathrm{K}$, Itoh $\mathrm{H}$. Lectin-like activity of Lactobacillus acidophilus strain JCM 1026. FEMS Microbioly Letters, 98 : 71-74. 1992.

7) Podolsky DK. Oligosaccharide structure of human colonic mucin. Journal of Biological Chemistry, 260 : 8262-8271. 1985.

8) Sellars RL. Acidophilus products. In : Therapeutic Properties of Fermented Milks. (Robinson RK. ed) 81-116. Elsevier. New York. 1991.

9) Takahashi N, Saito T, Ohwada S, Ota H, Hashiba H, Itoh T. A new screening method for the selection of Lactobacillus acidophilus group lactic acid bacteria with high adhesion to human colonic mucosa. Bioscience, Biotechnology and Biochemistry, 60:14341438. 1996.

10) Yamada M, Saito T, Toba T, Kitazawa H, Uemura J, Itoh T. Hemagglutination activity of Lactobacillus acidophilus group lactic acid bacteria. Bioscience, $B i$ otechnology and Biochemistry, 58 : 910-915. 1994. 